\title{
Household Indebtedness and Economic Growth (Empirical Analysis) ${ }^{\#}$
}

\author{
Vratislav IZÁK*
}

\section{Introduction}

One of the hypotheses tested in the literature devoted to the development of debt is that private debt surges are recurrently antecedent to banking crises (Reinhart - Rogoff, 2010). Ahead of banking crises, private debts also display a repeated cycle of boom and bust-the run up accelerates as the crisis nears. Further, banking crises most often either precede or coincide with sovereign debt crises and private debts become public debts after the crisis. One speaks about the pre-crisis surge of indebtedness in private sectors.

The resulting indebtedness in full-fledged market economies has been exacerbated by the financial and economic crisis (De Grauwe, 2011; Gonzalez-Paramo, 2011) and this in turn is contributing to underlying financial instability not only in the general government but also in private domestic sectors. When the general government has to raise saving to stabilize debt at the macrolevel, it is helpful if private sectors can run down savings to offset the negative impact on economic growth (see the famous formula stressing the relations between the public debt, primary budget balance, nominal interest rate and nominal economic growth). However, the euro area has resulted in high levels of debt not only in the general government sector, but also in the household and corporate sectors in many Member states (Blundell-Wignall, 2012, Dell’Ariccia et. al., 2012).

An important aspect of the indebtedness is the mutual influences between different sectors. For example, households in the United States and a number of other countries seem likely to spend less, save more and

\footnotetext{
\# The research has been supported as one of the products of the research project of The Faculty of Financing and Accounting at University of Economics, Prague, realized in the framework of the institutional support IP100040.

Prof. Ing. Vratislav Izák, CSc. - Professor; Department of Public Finance, Faculty of Finance and Accounting, University of Economics, Prague, W. Churchill Sq. 4, 13067 Prague, Czech Republic; <izak@vse.cz>.
} 
try to pay down debt. This seems likely to happen regardless of the capacity of banks to give indebted households more credit. According to White (2009), how the state of households and corporate balance sheets affects the desire to spend (as opposed to capacity to spend) is a crucial issue for future research.

Last, but not least, imbalances in household and corporate balance sheets can generally be matched by excessive leverage on the part of financial sector.

Therefore, alongside the government indebtedness, one must take into account also the debts of private agents, especially households and nonfinancial corporations indebtedness. In this paper our effort is concentrated on the household sector, especially the impacts on economic growth. After the introduction, in the second Section the brief literature overview is presented. The third Section deals with data and descriptive statistics whereas the fourth Section describes the results of panel regressions. The achieved results are summarized in conclusions.

\section{Literature overview}

The often discussed sustainability of public finances must tackle both the macroeconomic and sectorial levels. What is required is a framework where the sustainability conditions of all sectors are considered simultaneously, i.e. where the sustainability positions of all the sectors are related to each other. This is done by relating the financial balances of all the sectors (Berger, 2003).

When depicting the sustainability position of all the sectors in the economy simultaneously the sum of the balances must sum to zero. The total payments in the economy must equal the total receipts. A surplus run by one sector, e.g. general government, must be reflected as a deficit in one or more of the remaining sectors (Lequiller - Blades, 2006).

If one observes a general and continuous increase in general government/GDP ratios, it may be an indication of unsustainability not only in this sector but in the whole economy. Because the balances of all sectors have to sum zero, a deficit in the general government sector means that one or more of the non-governmental sectors will have to run a surplus. Hence unsustainability may be shifted from governmental to another sector of the economy, e.g. household or corporate sector. It 
means that the concepts of unsustainability and indebtedness must be broadened to overall, system-wide multi-sector concepts. Otherwise government runs the risk of indebtedness merely being "passed around" between sectors. If this happens, indebtedness may never truly be addressed unless it is flushed out of the economy by means of a spate of bankruptcies in household and corporate sectors (Burger, 2003, Cecchetti - Mohanty - Zampolli, 2011).

From the economic theory we know that borrowing allows individuals to smooth their consumption in the face of variable income. It allows governments to smooth taxes in the face of variable expenditures. It allows corporations to smooth investment and production in the face of variable sales. And it improves the efficiency of capital allocation across the various possible uses in the economy. Indebtedness can help smooth consumption not only through the lifetime of individuals who are currently alive, but also across generations (Blanchard - Amighini - Giavazzi, 2010).

The argument in favor of an intergenerational transfer is strengthened if part of general government debt is financing investment that will benefit future generations. The authors explore the impact of high debt on longrun economic growth (Kumar - Woo, 2010, Odedokun, 2001, Checherita, Rother, 2010, Cecchetti, Mohanty, Zampolli, 2011) suggesting a negative impact of high debt level on the longer-term economic growth and tackling thresholds, non-linearities, endogenity and a heap of subtle econometric problems. E. g. Checherita, Rother (2010) stress, for the 12 pooled euro-area countries, that for the debt-to-GDP ratio, turning point is roughly between 90 and $100 \%$ on average. This means that, on average for the 12 euro area countries, government debt-to -GDP ratios above such threshold would have a negative impact on economic growth.

The mainstream approaches (the Keynesian tradition, Buchanan) lead to the conclusion that public debt imposes a burden on future generations. To the extent that taxes levied to make interest payments on the debt are met by drawing down savings, the nation's store of capital stock will be reduced. It is the adverse impact on capital formation that represents the main burden of the public debt (Rowley - Shughart II - Tollison, 2002). The results of the majority of studies are unambiguous: high levels of debt are likely to be deleterious for growth. Particularly in a neoclassical setting, growth models augmented with public agents issuing debt to finance consumption tend to exhibit a negative relationship between public debt and economic growth (Barro - Sala-i-Martin, 1999). 
The channels through which debt (level or change) is found to have an impact on the economic growth are mainly: a) private saving, b) public investment, c) total factor productivity, d) sovereign long-term nominal and real interest rates.

Having summarized the results of empirical literature we conclude that not only the indebtedness of the general government but also the debts of e.g. households are worth of the empirical investigation.

\section{Data and descriptive statistics}

The source of data in this paper is represented by detailed national accounts published regularly by OECD (2012). The financial accounts and the balanced sheet accounts in the national accounts constitute the source of the household data. Flow of - funds accounts, though being an integral part of the National accounts, are devoted less attention compared to other economic aggregates. Sometimes are seen as a "difficult animal" (Bonci, 2011), left to statisticians and national accountants. The financial accounts show how the borrowing sectors obtain the financial resources they need and how the lender sectors allocate their surpluses. One can say that in general, non-financial corporations are globally borrowers while households are globally lenders.

A balance sheet is a statement, drawn up at a particular point in time, of the values of assets owned and of liabilities outstanding. The balancing item is called net worth. For the household sector the balance sheet shows the value of all assets and liabilities and the sector's net worth. ${ }^{1}$ Among thee liabilities the main item is "loans" and following other authors (Blundell-Wignall, 2012, Cecchetti, Mohanty and Zampolli, 2011) under the heading "household indebtedness" we understand loans. A loan is an asset for one sector (the lender) and a liability for another sector (the borrower).

In detailed national accounts we have at the disposal: a) 710 . Financial balance sheets-consolidated or non-consolidated and b) 610 . Financial accounts-consolidated or non-consolidated. The former record the stocks of financial assets and liabilities, at the end of the accounting period and the latter flows, which record, by type of financial instruments, the financial transactions between institutional sectors. Both are reported

1 The financial and balance sheet accounts, chapter 8 in Lequiller - Blades, 2006. 
at current prices in millions of national currency and in millions of Euros for OECD countries which are members of the Euro zone. Loans have a code F4 LI (liabilities) and F4 AS (assets).

We have gathered data for the time period 1995-2010 for the sample of 17 European OECD countries (in the parentheses cross identifiers used in panel analysis): Austria (AT), Belgium (BE), Germany (DE), Denmark (DK), Estonia (EE), Greece (EL), Spain (ES), Finland (FI), France (FR), Hungary (HU), Italy (IT), The Netherlands (NL), Norway (NO), Poland (PL), Portugal (PT), Sweden (SE), Slovakia (SK).

Using this relatively restricted cross-sectional sample helps mitigating the issue of heterogeneity with the caveat that postsocialist countries exhibit still differences vis-a-vis other members in the sample. According to X. Sala-i-Martin (1994) OECD countries converge to the same steady state because they appeal to be a homogenous set of countries.

We have put together sectors S14 Households and S15 Non-profit institutions serving households because some data are at the disposal for both sectors together.

Table 1 provides the main descriptive statistics for the ratios of loans on the net disposable income of households.

Tab. 1: Ratios of loans on the net disposable income of households (\%)

\begin{tabular}{|l|r|r|r|r|}
\cline { 2 - 5 } \multicolumn{1}{c|}{} & \multicolumn{1}{c|}{ Mean } & Maximum & Minimum & $\begin{array}{c}\text { Standard } \\
\text { deviation }\end{array}$ \\
\hline Austria & 82.07 & 96.15 & 66.33 & 9.12 \\
\hline Belgium & 71.74 & 93.15 & 57.10 & 10.76 \\
\hline Denmark & 245.26 & 333.20 & 166.75 & 54.40 \\
\hline Estonia & 43.18 & 103.81 & 3.31 & 37.87 \\
\hline Finland & 81.21 & 111.16 & 59.17 & 19.58 \\
\hline France & 63.66 & 81.49 & 54.31 & 9.67 \\
\hline Germany & 106.44 & 115.37 & 95.52 & 6.27 \\
\hline Greece & 39.81 & 90.23 & 7.92 & 27.73 \\
\hline Hungary & 31.47 & 75.19 & 6.64 & 24.90 \\
\hline Italy & 45.37 & 71.38 & 25.96 & 15.68 \\
\hline Netherlands & 202.03 & 285.41 & 112.84 & 58.37 \\
\hline
\end{tabular}




\begin{tabular}{|l|r|r|r|r|}
\cline { 2 - 5 } \multicolumn{1}{c|}{} & \multicolumn{1}{c|}{ Mean } & Maximum & Minimum & $\begin{array}{l}\text { Standard } \\
\text { deviation }\end{array}$ \\
\hline Norway & 150.57 & 194.55 & 116.86 & 31.62 \\
\hline Poland & 19.91 & 50.95 & 3.18 & 15.22 \\
\hline Portugal & 102.33 & 140.37 & 38.19 & 34.31 \\
\hline Slovakia & 24.48 & 58.90 & 8.46 & 18.70 \\
\hline Spain & 94.75 & 139.82 & 48.71 & 34.33 \\
\hline Sweden & 119.77 & 160.44 & 88.35 & 24.02 \\
\hline
\end{tabular}

Source: author's calculations.

The table shows high indebtedness of households especially in Denmark, The Netherlands, Norway and Sweden and still low indebtedness in postsocialist countries.

Interesting tendencies can be revealed looking at the development in time (ratios of loans on the net disposable income in different years, Tab.2).

Tab. 2: Development of loans in different years

\begin{tabular}{|l|r|r|r|r|r|r|r|r|r|r|}
\cline { 2 - 12 } \multicolumn{1}{c|}{} & $\mathbf{1 9 9 5}$ & $\mathbf{1 9 9 7}$ & $\mathbf{1 9 9 9}$ & $\mathbf{2 0 0 1}$ & $\mathbf{2 2 0 3}$ & $\mathbf{2 0 0 5}$ & $\mathbf{2 0 0 7}$ & $\mathbf{2 0 0 8}$ & $\mathbf{2 0 0 9}$ & $\mathbf{2 0 1 0}$ \\
\hline AT & 66.3 & 72.9 & 75.5 & 79.9 & 81.0 & 89.7 & 89.8 & 91.8 & 93.0 & 96.2 \\
\hline BE & 57.1 & 63.0 & 67.8 & 61.7 & 67.5 & 75.8 & 82.2 & 84.8 & 87.7 & 93.2 \\
\hline DE & 95.5 & 103.9 & 113.6 & 112.9 & 111.4 & 107.4 & 102.3 & 98.6 & 99.3 & 96.6 \\
\hline DK & 166.7 & 190.4 & 210.4 & 218.9 & 233.5 & 268.4 & 310.3 & 319.8 & 333.2 & 320.2 \\
\hline EE & 3.3 & 11.1 & 13.1 & 20.2 & 35.5 & 65.9 & 98.0 & 99.8 & 103.8 & 100.2 \\
\hline EL & 7.9 & 10.7 & 15.4 & 24.4 & 36.7 & 53.7 & 67.4 & 75.8 & 75.5 & 90.2 \\
\hline ES & 48.7 & 54.9 & 67.2 & 76.9 & 93.6 & 118.6 & 139.8 & 136.6 & 134.1 & 137.3 \\
\hline FI & 65.7 & 59.2 & 63.9 & 66.6 & 75.9 & 93.1 & 105.1 & 106.9 & 108.8 & 111.2 \\
\hline FR & 54.3 & 55.3 & 57.8 & 57.7 & 60.7 & 69.0 & 76.9 & 79.5 & 81.5 & 84.5 \\
\hline HU & 9.5 & 7.4 & 7.8 & 13.7 & 29.6 & 41.0 & 54.9 & 68.4 & 69.3 & 75.2 \\
\hline IT & 26.0 & 27.2 & 33.3 & 38.3 & 43.8 & 53.1 & 62.3 & 63.4 & 68.7 & 71.4 \\
\hline NL & 112.8 & 132.7 & 162.8 & 174.6 & 209.0 & 241.0 & 258.7 & 269.3 & 280.5 & 285.4 \\
\hline NO & 116.9 & 118.7 & 121.4 & 137.6 & 142.9 & 158.5 & 194.0 & 194.6 & 192.9 & 193.3 \\
\hline PL & 3.2 & 6.4 & 9.0 & 11.8 & 18.7 & 22.9 & 36.7 & 48.7 & 50.9 & 56.0 \\
\hline PT & 38.2 & 61.7 & 83.3 & 96.2 & 110.5 & 125.3 & 138.4 & 138.9 & 140.4 & 139.3 \\
\hline SE & 88.3 & 94.9 & 102.4 & 105.5 & 115.5 & 134.2 & 144.7 & 147.1 & 153.9 & 160.4 \\
\hline SK & 8.9 & 8.6 & 8.7 & 11.4 & 18.1 & 28.2 & 43.9 & 50.3 & 57.2 & 58.9 \\
\hline
\end{tabular}


The evidence from the table is clear.

Ratios of loans on the net disposable income have been increasing steadily in all countries of our sample. Remarkable is very low indebtedness of postsocialist states at the beginning of the examined period and their "catching up" during time. Conditional convergence (Barro - Sala-i-Martin, 1999) is probably also in this disguise.

The unweighted average of this ratio is shown in Fig. 1 where on the vertical axis the ratio of loans on the net disposable income is exhibited and the successive years are on the horizontal axis. The acceleration of indebtedness in the last years of financial and economic crisis can be revealed but this fact has been dwarfed by the trend that was ongoing over the entire examined period.

Fig. 1: Householddebts

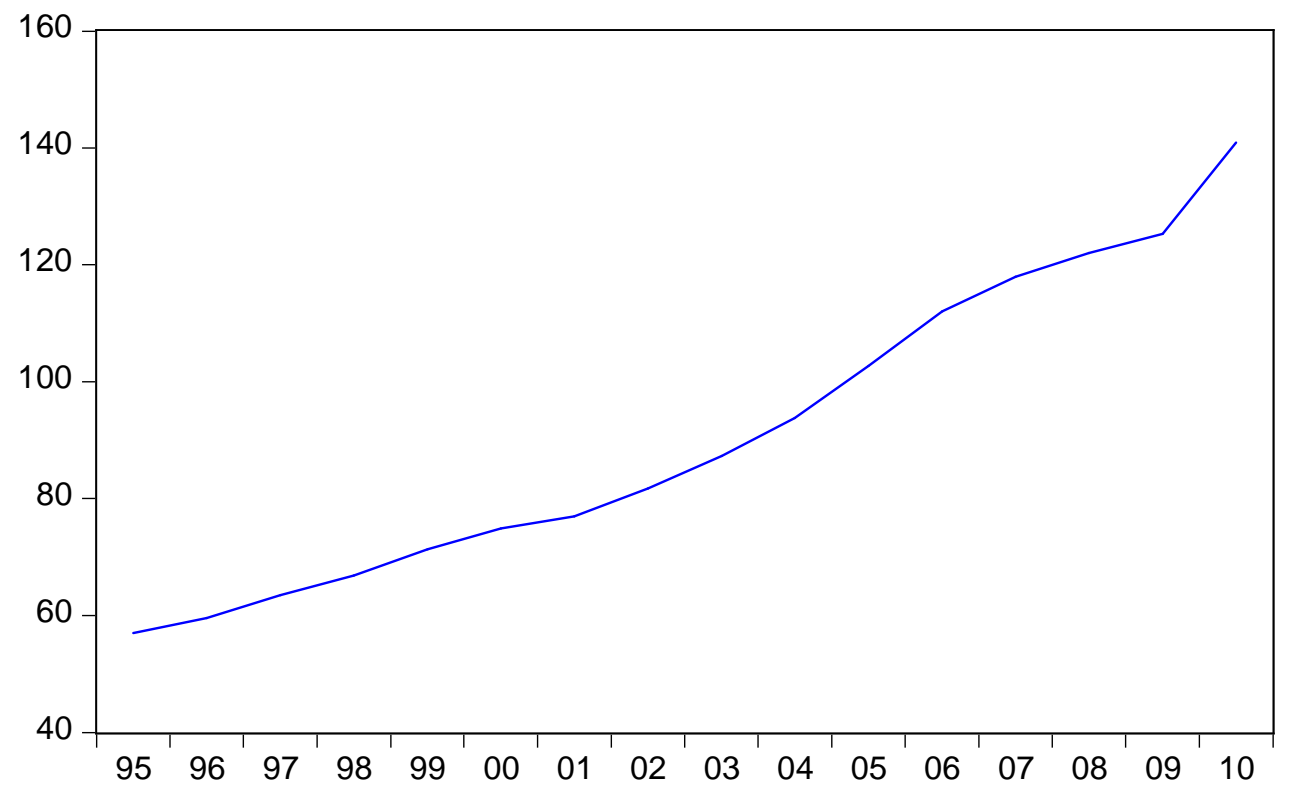

Source: author's calculations

The net disposable income in the household accounting is the difference between uses and resources. This key indicator represents the amount left at the disposal of households for either consumption or saving, over and above the replacement of the existing capital stock. It is 
called "net" because the amounts needed for the replacement of capital assets (dwellings and equipment of unincorporated enterprises) have already been deducted. ${ }^{2}$

Instead of the net disposable income the majority of researchers in discussing the indebtedness (mainly of the general government) have used the ratio of loans to the GDP in current prices. In the case of our sample the Fig. 2 demonstrates almost the perfect correlation between ratios of loans to the net disposable income and to the GDP in current prices.

\section{Fig. 2: Correlation between two means}

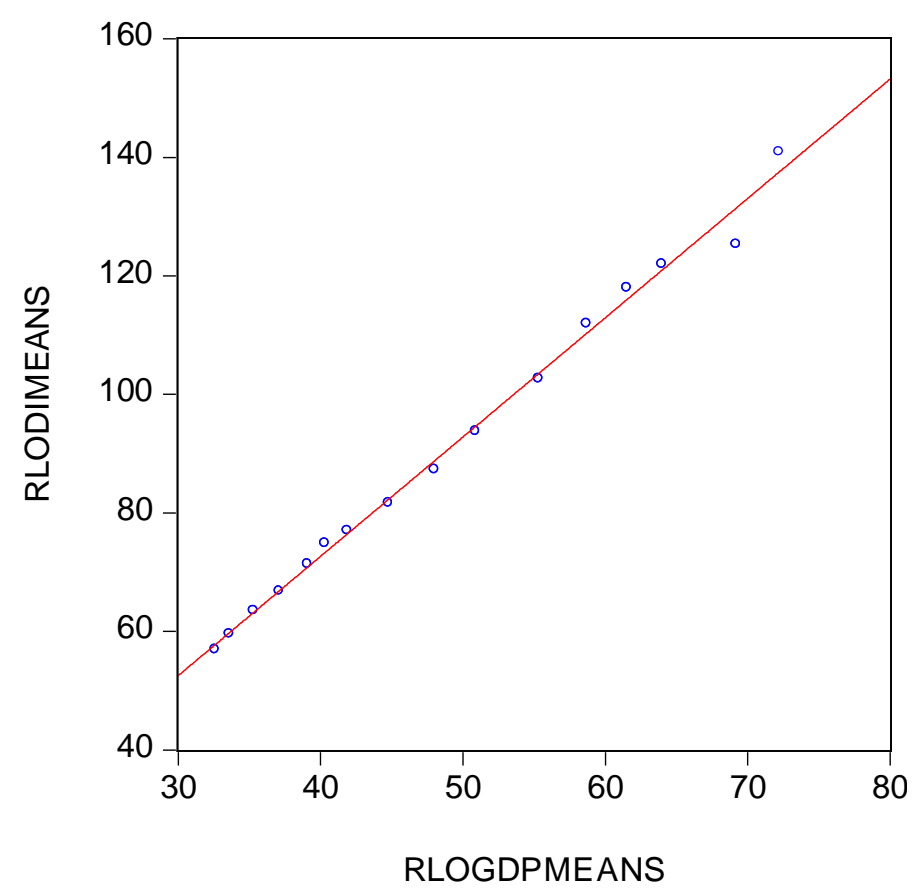

Source: author's calculations

The correlation coefficient between the two ratios of loans, as the graph indicates, is very high (0.996847), therefore it is irrelevant which ratio one uses. Our choice has been the net disposable income.

2 Some analysts prefer to use the gross disposable income, which is equal to the previous figure plus the consumption of fixed capital. More details see Lequiller Blades (2006). 


\section{Panel regressions}

Having discussed some descriptive statistics we now turn to running some forms of panel regressions to be able to detect the impact of hosehold indebtedness on economic growth. We start with basic regressions in the first step and then we add the households loans to these regressions.

In the spirit of Barro's approach we can write the growth regression as:

$$
\mathrm{y}_{\mathrm{it}}=\alpha \mathrm{Z}_{\mathrm{it}}+\beta \mathrm{l}_{\mathrm{it}}+\mathrm{u}_{\mathrm{it}}
$$

where $y=$ growth rate of real GDP,

$Z=$ vector of control variables,

$l=$ ratio of loans to the net disposable income,

$u=$ random term,

$\alpha, \beta=$ regression coefficients,

$i, t=$ subscripts (country and time subscripts, respectively).

\section{A) Basic panel regressions}

The usual starting point is the specification of a growth equation in the spirit of R.Barro's contributions. We use forward looking averages (2 and 3 years) of GDP growth rates and as the control variables we have the ratio of gross fixed capital formation on GDP in current prices and the growth rate of total labour force to represent the major input variables.

We employ moving average growth rate of GDP as the dependent variable (Ododekun, 2001, Devarajan et al, 1996, Kneller et al., 1999). The forward lag is chosen to reflect the fact that loans take time before their effects on output growth can be registered. It addresses also the joint endogeneity of the two variables and the possibility of reverse causality (Christiano et al., 1996). This problem exists in principle in our paper as well and one attempt to minimize it is by modelling loans in period $t$ as affecting growth from periods $\mathrm{t}+1$ through $\mathrm{t}+2$.

Control variables are not the variables whose parameter estimates are of immediate interest in this paper. But they are usually included so that the estimates of the e.g. fiscal variable parameters would be purged, as far as possible, from the imprecision due to errors of omitted variables. Some 
of examining control variables having been used in our paper include the initial level of income and terms of trade which are unlikely to be highly correlated with household loans. They have had proper signs but with low statistical significance, hence they have been omitted. By the way, having summarized the empirical literature till 1994 Sala-i-Martin (1994) asserted that over 50 variables had been found to be correlated with growth in at least one regression.

As concerns estimation methods we must discriminate between the common constant method, fixed effects method and random effect method. Table 3 describes the results of regressions using common constant method with three measures of the GDP growth rate.

\section{Tab. 3: Common constant method}

Estimation technique: Pooled EGLS (cross-section weights

\begin{tabular}{|l|r|r|r|}
\hline Independent variables & a & b & \multicolumn{1}{|c|}{$\mathbf{C}$} \\
\hline GFCF & 0.0887 & 0.0861 & 0.0997 \\
& $(2.61)$ & $(3.37)$ & $(5.08)$ \\
\hline Labour force growth & 0.3753 & 0.5017 & 0.3490 \\
& $(1.03)$ & $(1.94)$ & $(1.85)$ \\
\hline $\mathbf{N}$ & 255 & 255 & 238 \\
\hline $\mathbf{R}^{\mathbf{2}}$ adj & 0.07 & 0.14 & 0.18 \\
\hline
\end{tabular}

Note: t-statistic in parenthesis; a) growth rate, b) 2-year forward moving average of the GDP growth rate, c) 3-year forward moving average of the GDP growth rate. White cross-section standard errors \& covariances.

The conclusions that can be derived from Table 3 are:

a) signs for both explanatory variables are plus as expected;

b) statistically significant are coefficients for the ratio of GFCF on GDP; the significance for the growth rate of total labour force is lower;

c) the coefficient of determination is very low. 
The statistic values and the associated P-values in redundant fixed effects tests evaluating the joint significance of the cross-section effects using sum of squares ( $F$ test) strongly reject the null hypothesis that the cross-section effects are redundant.

The partial conclusion is that common constant method does not seem to be a proper method of estimation.

\section{Aa) Fixed effects}

Fixed effects capture economic and social characteristics specific for each country that remain broadly unchanged over time. The technique of fixed effect method caters for the existence of country-specific factors that do affect economic growth by allowing the intercept term to vary across countries. Since the Hausman test rejects the null hypothesis of no correlaton amongst the individual effects and the error term, we report only the results from the fixed effects models.

Due to the existence of large variation in the values of the regressors across countries in our sample, we correct for possible existence of heteroskedasticity by employing White's homoskedasticity-consistent estimation technique. As is well known this general test of heteroskedasticity does not relay on the normality assumption.

\section{Tab. 4: Fixed effects (cross)}

\begin{tabular}{|l|r|r|r|}
\hline \multicolumn{3}{|c|}{ Estimation technique: Pooled EGLS (cross-section weights } \\
\hline \multirow{2}{*}{ Dependent variable } & a & \multicolumn{1}{c|}{ b } & \multicolumn{1}{c|}{ C } \\
\hline Independent variables & & & \\
\hline GFCF & 0.2997 & 0.4647 & 0.4747 \\
& $(2.72)$ & $(3.86)$ & $(5.88)$ \\
\hline Labour force growth & 0.4085 & 0.4290 & 0.2520 \\
& $(1.34)$ & $(2.45)$ & $(2.65)$ \\
\hline $\mathbf{N}$ & 255 & 255 & 238 \\
\hline $\mathbf{R}^{\mathbf{2}}$ adj & 0.18 & 0.40 & 0.56 \\
\hline
\end{tabular}

Note: t-statistic in parenthesis; a) growth rate, b) 2-year forward moving average of the GDP growth rate, c) 3-year forward moving 
average of the GDP growth rate. White cross-section standard errors \& covariances.

The conclusions from the Table 4:

a) signs for both explanatory variables are plus as expected;

b) statistically significant are almost all coefficients;

c) coefficients of determination are high for lagged values of the dependent variable.

\section{B) Panel regressions with loans}

By adding loans as another explanatory variable we start again with common constant method.

\section{Ba) Common constant method}

The results are summarized in Table 5.

Tab. 5: Common constant method with loans

Estimation technique: Pooled EGLS (cross-section weights

\begin{tabular}{|l|r|r|r|}
\hline & Dependent variable & \multicolumn{1}{c|}{ a } & \multicolumn{1}{c|}{ C } \\
\hline Independent variables & & & \\
\hline GFCF & 0.1331 & 0.1362 & 0.1467 \\
& $(6.34)$ & $(9.78))$ & $(14.46)$ \\
\hline Labour force growth & 0.3152 & 0.3836 & 0.2171 \\
& $(1.00)$ & $(1.97)$ & $(1.69)$ \\
\hline Loans & -0.0090 & -0.0091 & -0.0080 \\
& $(-3.35)$ & $(-5.20)$ & $(-6.51)$ \\
\hline $\mathbf{R}_{\text {adj }}^{\mathbf{2}}$ & 0.14 & 0.23 & 0.29 \\
\hline
\end{tabular}

Note: loans are ratios of loans on the net disposable income. t-statistic in paranthesis; $\mathrm{a}, \mathrm{b}, \mathrm{c}$ as above. White robust errors and covariances.

From the table we see that a 10 percentage point increase in the ratio of loans to the net disposable income is associated with 9 basis point reduction in subsequent economic growth. The main result, gained from 
looking at the estimation, is the sign minus for the additional explanatory variable-households loans. The estimates are statistically significant, but very low.

The F-test again strongly rejects the null hypothesis that cross-section effects are redundant, hence we proceed with fixed effects method.

\section{Bb) Fixed effects}

Tab. 6: Fixed effects with loans

Estimation technique: Pooled EGLS (cross-section weights

\begin{tabular}{|l|r|r|r|}
\hline \multicolumn{1}{|c|}{ Dependent variable } & a & \multicolumn{1}{c|}{ b } & \multicolumn{1}{c|}{ c } \\
\hline Independent variables & & & \\
\hline GFCF & 0.2811 & 0.3747 & 0.3506 \\
& $(2.92)$ & $(6.31)$ & $(10.30$ \\
\hline Labour force growth & 0.3090 & 0.3837 & 0.2804 \\
& $(1.50)$ & $(3.15)$ & $(3.33)$ \\
\hline Loans & -0.0367 & -0.0343 & -0.0274 \\
& $(-2.64)$ & $(-4.62)$ & $(-5.53)$ \\
\hline $\mathbf{R}_{\text {adj }}^{\mathbf{2}}$ & 0.34 & 0.57 & 0.68 \\
\hline
\end{tabular}

Note: t-statistic in parenthesis; $a, b$,c as above. White cross-section standard errors \& covariances.

According to the Table 6 a 10 percentage point increase in the ratio of household loans to the net disposable income is associated with about 30 basis point reduction in lagged economic growth. The regression coefficients have a consistently negative impact on growth. The impact of loans on the growth rate of GDP is again with sign minus and statistically significant not only for current growth rate of GDP but also for lagged values. Coefficients of determination are high especially for lagged values of dependent variable.

More profound look can be gathered by studying the cross-specific coefficients for individual countries. From 17 countries the sign minus for loans have been discovered at 14 countries (10 coefficients have been statistically significant with $\mathrm{P}<0.05)$ for the 2-year forward moving 
average of the dependent variable. Similar results have been revealed for the 3-year forward moving average.

Last but not least we have studied the results with period specific coefficients (for 2- and 3-forward moving averages of the growth rate of GDP from the year 1996 and 1997, respectively).

The signs oscillate between minus and plus but in the last 3 years the signs are minus with very high significance for the years 2009 and 2010 $(\mathrm{P}=0.00)$ for both kinds of lagged growth variables. Some authors (Kumar - Woo, 2010; Cecchetti et al., 2011; Checherita - Rother 2010) claim, that at moderate levels, debt improves welfare and enhances growth and estimate the thresholds beyond which the debt becomes a drag on growth. This could be, at least partially, the explanation of the results for the crisis years 2009 and 2010.

\section{More homogenous panel}

The homogeneity of the examined sample can be increased, following descriptive statistic in Table 1, by putting aside 4 postsocialist countries (showing still low indebtedness). The narrowed sample is composed from 13 countries representing full fledged market economies.

The similar exercise, whose results have been shown in Table 6, exhibits a bit higher coefficients for loans. E.g. for the 2-year forward moving average of growth rate a 10 percentage point increase in the ratio of loans to the net disposable income is associated with 37 basis point reduction in subsequent economic growth (details are at the author).

The repeated exercise using the cross-specific coefficients for 13 individual countries is examined in Table 7.

\section{Tab. 7: Cross-specific coefficients for individual countries}

Estimation technique: Pooled EGLS (cross-section weights

\begin{tabular}{|l|c|r|r|}
\hline Dependent variable & a & b & c \\
\hline Independent variables & & & \\
\hline GFCF & 0.0303 & 0.0447 & 0.0365 \\
& $(1.69)$ & $(6.22)$ & $(9.73)$ \\
\hline
\end{tabular}


Izák, V.: Household Indebtedness and Economic Growth (Empirical Analysis).

Estimation technique: Pooled EGLS (cross-section weights

\begin{tabular}{|l|r|r|r|}
\hline \multicolumn{1}{|c|}{ Dependent variable } & \multicolumn{1}{c|}{ a } & \multicolumn{1}{c|}{ b } & \multicolumn{1}{c|}{ c } \\
\hline Independent variables & & & \\
\hline TLF & -0.0013 & -0.0011 & -0.0008 \\
& $(-2.40)$ & $(-3.77)$ & $(-3-93)$ \\
\hline Loans Austria & -0.0604 & -0.0892 & -0.0764 \\
& $(-1.07)$ & $(-2.01)$ & $(-2.13)$ \\
\hline Loans Belgium & -0.0531 & -0.0867 & -0.0756 \\
& $(-0.94)$ & $(-2.90)$ & $(-3.80)$ \\
\hline Loans Denmark & -0.0501 & -0.0606 & -0.0476 \\
& $(-2.08)$ & $(-8.76)$ & $(-12.01)$ \\
\hline Loans Finland & -0.0774 & -0.0866 & -0.0691 \\
& $(-1.34)$ & $(-2.40)$ & $(-2.75)$ \\
\hline Loans France & -0.1702 & -0.2522 & -0.2136 \\
& $(-1.68)$ & $(-5.24)$ & $(-7.75)$ \\
\hline Loans Germany & 0.1051 & 0.0480 & 0.0110 \\
& $(1.31)$ & $(0.89)$ & $(0.33)$ \\
\hline Loans Greece & -0.0576 & -0.0557 & -0.0454 \\
& $(-2.73)$ & $(-2.66)$ & $(-2.29)$ \\
\hline Loans Italy & -0.0767 & -0.1299 & -0.1129 \\
& $(-1.21)$ & $(-4.98)$ & $(-7.02)$ \\
\hline Loans Netherlands & -0.0174 & -0.0239 & -0.0223 \\
& $(-1.75)$ & $(-3.83)$ & $(-5.10)$ \\
\hline Loans Norway & -0.1424 & -0.1897 & -0.1543 \\
& $(-1.99)$ & $(-5.41)$ & $(-7.03)$ \\
\hline Loans Portugal & -0.0416 & -0.0498 & -0.0564 \\
& $(-4.56)$ & $(-5.81)$ & $(-7.48)$ \\
\hline Loans Spain & -0.0066 & -0.0465 & -0.0487 \\
& $(-0.25)$ & $(-2.43)$ & $(-3.54)$ \\
\hline Loans Sweden & -0.1595 & -0.2345 & -0.1925 \\
& $(-1.47)$ & $(-6.19)$ & $(-9.78)$ \\
\hline N & 206 & 193 & 180 \\
\hline$R_{\text {adj }}^{2}$ & 0.32 & 0.62 & 0.74 \\
\hline & & & \\
& & & \\
& & &
\end{tabular}


Note: t-statistic in parenthesis; a, b, c as above. White cross-section standard errors \& covariances.

All coefficients with the exception of Germany have expected proper sign minus and are statistically significant for both kinds of lagged growth variables. Very high coefficients are displayed especially for France, Italy, Sweden and Norway. E.g. for France a 10 percentage point increase in the loan ratio is associated with 252 basis point reduction in 2 year lagged growth.

Last but not least to complete our analysis we compute period-specific coefficients (Table 8)

\section{Tab. 8: Period-specific coefficients}

Estimation technique: Pooled EGLS (cross-section weights

\begin{tabular}{|l|r|r|r|}
\hline \multicolumn{1}{|c|}{ Dependent variable } & \multicolumn{1}{c|}{ a } & \multicolumn{1}{c|}{ b } & \multicolumn{1}{c|}{ c } \\
\hline Independent variables & 0.0005 & 0.0010 & 0.0011 \\
& $(0.22)$ & $(0.52)$ & $(0.70)$ \\
\hline TLF & -0.0003 & -0.0002 & -0.0002 \\
& $(-3.97)$ & $(-2.78)$ & $(-2.56)$ \\
\hline Loans 1995 & -0.0133 & $\mathrm{Na}$ & $\mathrm{Na}$ \\
& $(-0.90)$ & & \\
\hline Loans 1996 & -0.0180 & -0.0189 & $\mathrm{Na}$ \\
& $(-1.18)$ & $(-1.63)$ & \\
\hline Loans 1997 & -0.0073 & -0.0157 & -0.0165 \\
& $(-0.52)$ & $(-1.37)$ & $(-1.87)$ \\
\hline Loans 1998 & -0.0084 & -0.0112 & -0.0155 \\
& $(-0.68)$ & $(-1.07)$ & $(-1.85)$ \\
\hline Loans 1999 & -0.0059 & -0.0103 & -0.0113 \\
& $(-0.47)$ & $(-1.01)$ & $(-1.36)$ \\
\hline Loans 2000 & -0.0018 & -0.0065 & -0.0092 \\
& $(-0.15)$ & $(-0.63)$ & $(-1.15)$ \\
\hline Loans 2001 & -0.0203 & -0.0143 & -0.0135 \\
& $(-1.64)$ & $(-1.50)$ & $(-1.76)$ \\
\hline
\end{tabular}


Izák, V.: Household Indebtedness and Economic Growth (Empirical Analysis).

\begin{tabular}{|c|c|c|c|}
\hline \multicolumn{4}{|c|}{ Estimation technique: Pooled EGLS (cross-section weights } \\
\hline $\begin{array}{l}\text { Dependent variable } \\
\text { Independent variables }\end{array}$ & $\mathbf{a}$ & b & c \\
\hline Loans 2002 & $\begin{array}{r}-0.0239 \\
(-1.95)\end{array}$ & $\begin{array}{r}-0.0251 \\
(-2.61)\end{array}$ & $\begin{array}{r}-0.0190 \\
(-2.60)\end{array}$ \\
\hline Loans 2003 & $\begin{array}{r}-0.0250 \\
(-1.91)\end{array}$ & $\begin{array}{r}-0.0270 \\
(-2.66)\end{array}$ & $\begin{array}{r}-0.0265 \\
(-3.40)\end{array}$ \\
\hline Loans 2004 & $\begin{array}{r}-0.0095 \\
(-0.84)\end{array}$ & $\begin{array}{r}-0.0191 \\
(-1.97)\end{array}$ & $\begin{array}{r}-0.0216 \\
(-2.80)\end{array}$ \\
\hline Loans 2005 & $\begin{array}{r}-0.0125 \\
(-1.12) \\
\end{array}$ & $\begin{array}{r}-0.0131 \\
(-1.45) \\
\end{array}$ & $\begin{array}{r}-0.0178 \\
(-2.37) \\
\end{array}$ \\
\hline Loans 2006 & $\begin{array}{r}-0.0051 \\
(-0.48) \\
\end{array}$ & $\begin{array}{r}-0.0108 \\
(-1.25) \\
\end{array}$ & $\begin{array}{r}-0.0111 \\
(-1.65)\end{array}$ \\
\hline Loans 2007 & $\begin{array}{r}-0.0062 \\
(-0.63)\end{array}$ & $\begin{array}{r}-0.0078 \\
(-0.95)\end{array}$ & $\begin{array}{r}-0.0139 \\
(-1.61)\end{array}$ \\
\hline Loans 2008 & $\begin{array}{r}-0.0209 \\
(-1.97) \\
\end{array}$ & $\begin{array}{r}-0.0164 \\
(-1.92) \\
\end{array}$ & $\begin{array}{r}-0.0139 \\
(-2.13) \\
\end{array}$ \\
\hline Loans 2009 & $\begin{array}{r}-0.0448 \\
(-3.83) \\
\end{array}$ & $\begin{array}{r}-0.0367 \\
(-3.72) \\
\end{array}$ & $\begin{array}{r}-0.0285 \\
(-3.81) \\
\end{array}$ \\
\hline Loans 2010 & $\begin{array}{r}-0.0133 \\
(-1.50) \\
\end{array}$ & $\begin{array}{r}-0.0311 \\
(-3.68) \\
\end{array}$ & $\begin{array}{r}-0.0295 \\
(-4.14) \\
\end{array}$ \\
\hline $\mathbf{N}$ & 206 & 193 & 180 \\
\hline $\mathbf{R}^{2}{ }_{\text {adj }}$ & 0.66 & 0.71 & 0.75 \\
\hline
\end{tabular}

Note: t-statistic in parenthesis; a, b, c as above. White period standard errors \& covariance (White period method assumes that the errors for a cross-section are heteroskedastic and serially correlated (cross-section clustered).

For all 16 years the signs for loan coefficients are minus in spite of the fact that in some years the statistic purged by using White period standard errors is insignificant. The most convincing results are displayed with the 3 -year forward moving average of the growth rate as the dependent variable (10 period specific coefficients have P-value lower than 0.08 ). 
The loan coefficients exhibit the highest values in the years 2009 and 2010 which is in accordance with our results above in this paper.

\section{Conclusion}

It is well known from the literature that the sustainability conditions of all sectors must be considered simultaneously, because all the sectors of national economy are related to each other. In the paper we stress, that alongside the general government indebtedness, one must take into account also the debts of private agents, in this case those of households.

The source of data is represented by detailed national accounts published regularly by OECD (the financial accounts and the balanced sheets accounts). We have gathered data for the time period 1995-2010 for the sample of 17 European OECD countries. We have put together sectors S14 Households and S15 Non-profit institutions serving households because some data are at the disposal for both sectors together.

Ratios of loans on the net disposable income of households show high indebtedness especially in Denmark, The Netherlands, Norway and Sweden and still low indebtedness in postsocialist countries. Ratios have been increasing steadily in all countries of our sample. Remarkable is very low indebtedness of postsocialist countries at the beginning of the examined period and their "catching up" during time.

Having discussed some descriptive statistics we ran some forms of panel regressions to be able to detect the impact of household indebtedness on economic growth. We started with the growth regression in the spirit of R. Barro and then we added the household loans to this regression. As control (conditional) variables we used the ratio of gross fixed capital formation on GDP in current prices and the growth rate of total labor force. We employed moving average growth rate of GDP as the dependent variable. The forward lag was chosen to reflex the fact that loans take time before their effects on output growth can be registered. It addresses also the joint endogeneity of the two variables and the possibility of reverse causality. This problem exists in principle in our paper as well and one attempt to minimize it is by modeling loans in period $t$ as affecting growth from periods $t+1$ through $t+2$.

We discriminated between the common constant method, fixed effects method and random effect method. The statistic tests preferred fixed 
effects capturing economic and social characteristics for each country that remain broadly unchanged over time. In basic growth equation signs for both control variables were plus as expected and statistically significant for almost all coefficients. In panel equation with loans (fixed effects, Table 6) a 10 percentage point increase in the ratio of household loans to the net disposable income is associated with about 30 basis point reduction in lagged economic growth.

More profound look can be gathered by studying the cross-specific coefficients for individual countries. From 17 countries the sign minus for loans have been discovered at 14 countries. Coefficients of determination are high especially for lagged values of dependent variable. Last but not least the results with period specific coefficients show that the signs oscillate between minus and plus but in the last 3 years the signs are minus with very high significance for the years 2009 and $2010(\mathrm{P}=0.00)$ for both kinds of lagged growth variables. Especially in these years the household indebtedness has become a drag on economic growth.

The homogeneity of the examined sample has been increased by putting aside 4 postsocialist countries showing still low indebtedness. The similar exercise as in Table 6 shows e.g. that for the 2-year forward moving average of growth rate a 10 percentage point increase in the ratio of loans to the net disposable income is associated with 37 basis point reduction in subsequent economic growth. In Table 7 using cross-specific coefficients for 13 individual countries all coefficients with the exception of Germany have expected proper sign minus and are statistically significant. To complete the analysis we have computed period-specific coefficients (Table 8). The most convincing results are displayed with the 3-year forward moving average of the growth rate as the dependent variable (10 period specific coefficients have P-value lower than 0.08).

In spite of the fact that correlation does not mean causation and the known problems with both short and long panels used in macroeconomics (Judson - Owen, 1999) it seems that growing household indebtedness has contributed to the lower economic growth in European OECD countries. The sustainability of public finances must therefore tackle also the growing indebtedness of the sectors household and non-profit institutions serving households. 


\section{References}

[1] Barro, R. - Sala-i-Martin, X. (1999): Economic Growth. Cambridge, Massachusetts Institute of Technology Press, 1999.

[2] Blanchard, O. - Amighini, A. - Giavazzi, F. (2010): Macroeconomics, A European Perspective. Upper Saddle River, Prentice Hall, 2010.

[3] Blundell-Wignall, A. (2012): Solving the Financial and Sovereign Debt Crisis in Europe. Financial Market Trends, 2011, no. 2,

[4] Bonci, R. (2011): Monetary Policy and the Flow of Funds in the Euro Area. [on-line], Frankfurt am Main, European Central Bank, Working Paper Series no. 1042, c2011, [cited $13^{\text {th }}$ July, 2012], <http://www.ecb.europa.eu/pub/pdf/scpwps/ecbwp1402.pdf>.

[5] Burger, P. (2003): Sustainable Fiscal Policy and Economic Stability. Theory and Practice. Cheltenham, Edward Elgar, 2003.

[6] Cecchetti, S. G. - Mohanty, M. S. - Zampolli, F. (2011): The Real Effects of Debt. [on-line], Basel, Bank for International Settlements, Working Paper no. 352, c2011, [cited $13^{\text {th }}$ July, 2012], <http://www.bis.org/publ/othp16.pdf>.

[7] De Grauwe, P. (2011): The European Central Bank: Lender of Last Resort in the Government Bond Markets? [on-line], München, Center for Economic Studies, Working Paper no. 3569, c2011, [cited $13^{\text {th }}$ July, 2012], <http://www.cesifo-group.de/portal/pls/portal/docs/1/1211348.PDF>.

[8] Dell'Ariccia, G. - Igan, D. - Laeven, L. - Tong, H. (2012): Policies for Macrofinancial Stability: How to Deal with Credit Booms. [on-line], Washington, D. C., International Monetary Fund Staff Discussion Note 12/06, c2012, [cited $13^{\text {th }}$ July, 2012], <http://www.imf.org/external/pubs/ft/sdn/2012/sdn1206.pdf>.

[9] Devarajan, S. - Swaroop, V. - Zou, H. (1996): The Composition of Public Spending Expenditure and Economic Growth. Journal of Monetary Economics, 1996, vol. 37, no. 2, pp. 313-344.

[10] Gonzalez-Paramo, J. M. (2011): The ECB's Monetary Policy during the Crisis. [on-line], Frankfurt am Main, European Central Bank, c2011, [cited $13^{\text {th }}$ July, 2012], <http://www.ecb.int/press/key/date/2011/html/sp111021_1.en.html>. 
[11] Checherita, C. - Rother, P. (2010): The Impact of High and Growing Government Debt on Economic Growth: An Empirical Investigation for the Euro Area. [on-line], Frankfurt am Main, European Central Bank, Working Paper Series no. 1237, c2010, [cited 13 ${ }^{\text {th }}$ July, 2012], <http://www.ecb.int/pub/pdf/scpwps/ecbwp1237.pdf>.

[12] Christiano, L. - Eichenbaum, M. - Evans, C. (1996): The Effects of Monetary Policy Shocks: Evidence from the Flow of Funds. Review of Economics and Statistics, 1996, vol. 78, no 1, pp.16-34.

[13] Judson, R. - Owen, A. (1999): Estimating Dynamic Panel Data Models: A Guide for Macroeconomists. Economics Letters, 1999, vol. 65, no. 1, pp. 9-15.

[14] Kneller, R. - Bleaney, M. F. - Gemmell, N. (1999): Fiscal policy and Growth: Evidence from OECD Countries. Journal of Public Economics, 1999, vol. 74, no. 2, pp.171-190.

[15] Kumar, M. S. - Woo, J. (2010): Public Debt and Growth. [on-line], Washington, D. C., International Monetary Fund Working Paper no. 10/174, c2010, [cited $13^{\text {th }}$ July, 2012], <http://www.imf.org/external/pubs/ft/wp/2010/wp10174.pdf>.

[16] Lequiller, F. - Blades, D. (2006): Understanding National Accounts. [on-line], Paris, Organization for Economic Co-operation and Development, c2006, [cited $13^{\text {th }}$ July, 2012], <http://www.oecd.org/std/nationalaccounts/38451313.pdf>.

[17] Odedokun, M. O. (2001): Public Finance and Economic Growth. Empirical Evidence from Developing Countries. [on-line], Helsinki, United Nations University / World Institute for Development Economics Research, Discussion Paper, no. 2001/72, c2001, [cited $13^{\text {th }}$ July, 2012], <https://www.econstor.eu/dspace/bitstream/10419/52829/1/3351287 26.pdf $>$.

[18] OECD (2012): OECD Statistics. National Accounts. [on-line], Paris, Organisation for Economic Cooperation and Development, c2012, [cited $13^{\text {th }}$ July, 2012], <http://www.oecd.org/statistics>.

[19] Reinhart, C. M. - Rogoff, K. S. (2010): From Financial Crash to Debt Crisis. [on-line], Washington, D. C., National Bureau of Economic Research, Working Paper no. 15795, c2010, [cited $13^{\text {th }}$ July, 2012], 〈http://www.nber.org/papers/w15795.pdf>. 
[20] Rowley, C. K. - Shughart II, W. F. - Tollison, R. D. (2002): The Economics of Budget Deficits. Cheltenham, Edward Elgar, 2002.

[21] Sala-i-Martin, X. (1994): Cross-sectional Regressions and the Empirics of Economic Growth. European Economic Review, 1994, vol. 38, no. 3-4, pp.739-747.

[22] White, W. (2009): Modern Macroeconomics is on the Wrong Track. Finance \& Development, 2009, vol. 46, no. 4, pp. 15-19. 


\title{
Household Indebtedness and Economic Growth (Empirical Analysis)
}

\author{
Vratislav IZÁK
}

\begin{abstract}
One important aspect of the resulting indebtedness in full-fledged market economies is the mutual influence between different economic sectors. Therefore, alongside the government indebtedness, one must take into account also the debts of private agents, especially of households and non-financial corporations. In this paper our effort is concentrated on the household sector, especially the impacts on economic growth.

We have gathered data for the time period 1995-2010 for the sample of 17 European OECD countries. The main descriptive statistics reveal high and still increasing indebtedness (ratio on the net disposable income) especially in Denmark, The Netherlands, Norway and Sweden and still low indebtedness in postsocialist countries.

In panel regressions (fixed effects) we add loans as another explanatory variable into growth equation and examine the impacts on the growth rate of real GDP. The main result shows that a 10 percentage point increase in the ratio of household loans to the net disposable income is associated with about 30 basis point reduction in lagged economic growth. More profound looks give the study of both cross-specific and period-specific coefficients. Last but not least we have examined more homogenous panel of 13 countries putting aside 4 postsocialist countries.
\end{abstract}

Key words: Households loans; Economic growth; Panel analysis (fixed effects).

JEL classification: $\mathrm{H} 3, \mathrm{E} 1, \mathrm{O} 4$. 